\title{
Educational Leadership in Our Peculiar Institutions: Understandings of Principals in Segregated, White-Staffed Urban Elementary Schools in the United States
}

\author{
Tonya Milligan \\ Columbus City Schools \\ U.S.A. \\ Craig Howley \\ WordFarmers Associates \\ U.S.A.
}

ABSTRACT: This study explores how 10 principals in mostly-Black U.S. urban elementary schools staffed by mostly-White faculty understood and experienced the manifestations of racial differences. Narrative inquiry with nearly 700 pages of transcript data yielded three themes: (1) gradients of color-conscious leadership, (2) principals as moral agents, and (3) working within a context of fear. Difficult though these stories and challenges are in the U.S., practices and policies elsewhere in the world also produce such situations and experiences, and the dynamics evident in the stories told by these school heads may prove relevant to investigations in other national systems.

KEYWORDS: educational leadership, urban school, elementary principal, colorconscious leadership, moral agency

\author{
Purpose of Study \\ Methodology \\ Research Design \\ Findings \\ Discussion \\ References \\ Author Contact
}

I've not lived the Black experience. I mean I might know about it, but I haven't lived it. I can't talk or relate to them [students] like that, and they know that. It's nobody's fault, it's just the way life is. I haven't been there. I haven't done that. A lot of White teachers that are here have not done that either. I mean they all drive to the suburbs to their little homes, and I don't know that they understand completely everything that goes on in the neighborhood.

Daniel, White elementary principal 
Schooling in the United States today is as much about race as it was 60 years ago prior to the landmark decision in Brown v. Board of Education (1954). School segregation for Blacks, for example, has increased dramatically since the height of desegregation efforts in the 1980s, resulting in a level of segregation not experienced since the Civil Rights era (Orfield, 2009). According to a report by the Civil Rights Project (Orfield, Kucsera, \& Siegel-Hawley, 2012), 74\% of Black students in the United States attend majority non-White schools $(50-100 \%$ minority), $38 \%$ of Black students attend intensely segregated schools $(0-10 \%$ White students), and 15\% of Black students attend "apartheid schools" (p. 9) where only $0-1 \%$ of the students are White. Students in most segregated US urban schools will, however, also experience separation by both race and poverty, with some schools having poverty rates over 90\% (Orfield et al., 2012), and such concentrations of poverty within schools may be even more strongly linked to educational inequity than racial segregation (Reardon, 2011). Further complicating the difficulties for urban Black children is the fact that their schools are often staffed predominantly with White teachers (Boser, 2014). Although minority teachers are two to three times more likely than White teachers to work in urban schools, less than $30 \%$ of urban school teachers in the Unites States are minority (Ingersoll \& May, 2011).

According to cultural capital theory, the mismatch between teachers and students results in cultural misunderstandings and misinterpretations which complicate teacher-student interactions (Lareau \& Weininger, 2003). Unfortunately, according to astute observers, schooling in the United States caters to the dominant, White, middle-class standards of behavior and academic ability (Delpit, 1995; McGrady \& Reynolds, 2013). The inequitable outcomes of this schooling dynamic are predictable: more frequent and more severe discipline for minority students in comparison to their White counterparts (Monroe, 2005) and a substantial achievement gap between wealthier White students and impoverished minority students (Ferguson \& Mehta, 2004).

Critical race theory (CRT) provides an analytical framework for exploring educational leadership in these White-staffed segregated schools. CRT, a framework developed by legal scholars, examines and seeks to challenge ways in which racism and White privilege work in concert to dominate institutions and systems (Delgado \& Stefancic, 2001). CRT theorists (e.g., Dixon \& Rousseau, 2005; Ladson-Billings, 2005) argue that racism should be understood as both ordinary and interwoven into the societal fabric of life in the United States. On this view, the persistence of White-staffed segregated schools for impoverished Black communities is predictable and does predictable damage to students, families, and communities.

Although circumstances in the United States are historically and politically specific, the phenomenon of ghetto schooling, with difficult cultural dynamics inscribed in processes of ghettoization (e.g., Wacquant, 2007), exists in many regions and nations across the planet (e.g., Love \& Varghese, 2012). One thinks of the troubled banlieux in France, of the Romani across Europe, and of minority religious and cultural groups everywhere. While the absence of research interest 
in schools with such circumstances is understandable (research representing an elite enterprise overall), we hope that this study can help encourage others to examine the experiences of educators and families thrust into unfamiliar context and contacts.

\section{Purpose of Study}

Recent scholarship on race, racism, and the urban principalship includes research on social justice leaders (Theoharis, 2007), anti-racist leadership (Brooks \& Witherspoon-Arnold, 2013; McMahon, 2007; Singleton \& Linton, 2005), and culturally relevant leadership (Horsford, Grosland, \& Gunn, 2011). Such work in the United States, however, tends to study principals who embrace social justice ideas and who lead in schools that are considered "diverse" as opposed to segregated. Our study, by contrast, identified segregated urban elementary schools and interviewed their principals. Schools in which the teaching staff is culturally at odds with the student population are becoming an increasingly prevalent school leadership context in the United States (Evans, 2004; Houck, 2010). Addressing the need for school leadership research in this context is both practically and theoretically important. The study was guided by two questions:

1. How do urban school principals understand urban schools where the majority of students are Black and the majority of teachers are White?

2. How does this understanding influence their leadership?

\section{Methodology}

We used narrative inquiry as the methodology for this study. This methodological approach inquires into the stories of others and retells these stories as a means of capturing the array of experiences, insights, and observations that influence one's understandings (Clandinin \& Connelly, 2000). Exploring educational leadership in this way allowed us to gain "a broader and more representative understanding of the complexity of school landscapes and the positioning of leaders in those landscapes" (Clandinin, Pushor, \& Orr, 2007, p. 30). Much of the relevant literature, however, has used positivist approaches to characterize urban school leadership. Using narrative inquiry, we believe, can provide a richer and more appropriately complex representation of educational leadership in segregated Black schools staffed mostly with White teachers. 


\section{Research Design}

Because of the complexity of the urban education context and the discomfort sometimes caused by race-based dialogue, especially for Whites (Howard, 2006), we chose an in-depth interviewing method (Seidman, 2006), scheduling a series of three 90-minute interviews across three to four weeks. This procedure established a level of trust needed to mitigate or dispel the discomfort of talking about socially difficult topics. We used a semi-structured interview protocol to guide the data collection, but the interviews, as Seidman (2006) advises, paid close attention to the participants' responses and concerns.

\section{Data Collection}

Using the state Department of Education's database, we purposefully selected 10 elementary schools that exhibited majority-Black (non-Hispanic) students, majority-White teachers, and a high rate of neighborhood poverty (subsidized meal rate of the school). Schools were located in three cities in a Midwest state. We recruited the principals of these schools: three White females, three Black females, two White males, and two Black males. Participants agreed to the series of interviews, which took place at their school sites. Interviews were digitally recorded and transcribed verbatim; the over 700 pages of transcript served as the primary source of data, complemented by field notes. Pseudonyms identify principals and their schools.

\section{Data Analysis}

We transcribed interviews and compared the transcriptions to the digital recordings for accuracy. We used cycles of reflection and revision as well, throughout the data collection, and made notes about anything that seemed significant to the participant and relevant to the overall study. Throughout the interviewing process and the data analysis, we shared transcript data and any analytical thoughts with research participants to determine accurate representation of the data and to safeguard against the influence of our own preconceived understandings and biases. According to Miles, Huberman, and Saldaña (2013), this type of member checking, by minimizing errors and misinterpretation of data, improves credibility and validity.

A preliminary review of the data indicated that while all participants were aware of the racialized context of their schools, they tended to problematize this context differently and to different degrees. We began to explore the extent of these differences by placing the participants on a continuum based on the extent 
to which the data indicated that each participant problematized race-based situations in their school ("I try not to make it about race but some things just are"). Coding of the data proceeded by analyzing transcripts from two participants that fell on opposite ends of the continuum, line-by-line, creating multiple, descriptive codes to portray the data. Saldaña (2013) refers to this process as first cycle coding. We explored commonalities and identified conceptual similarities to create axial codes that encompassed the totality of the experiences shared by participants (Saldaña, 2013). We then used the axial codes to code the remaining transcripts.

Throughout the coding process, we used memoing to capture ideas regarding emergence of nascent themes. Additionally, to guard against oversimplification of the data and to avoid drawing premature conclusions, we used matrices to visualize the data numerically and to explore salient characteristics for each participant as well as any connections between participants (Miles \& Huberman, 1994).

Exploring the connections among participants, we identified three themes that collectively described the participants' understandings and experiences: (a) gradients of color-conscious leadership; (b) principals as moral agents; and (c) working within a context of fear. Once the three themes were identified, the transcripts were again re-analyzed to identify passages that supported each theme. This re-analysis helped identify counterfactuals, refined our understanding of the theme, and served as an audit trail to account for the findings.

\section{Validity}

Limitations and threats to validity exist, even with a careful and systematic approach to the study. Three seem most relevant in this case. First, as two White researchers engaged in a study focused on issues of race and racism, we faced the blinders of our own racial identities (see, for example, Sue \& Sue, 2008). Study advisors, however, included African Americans who served as critical friends and helped us confront such limitations by engaging in ongoing dialogue throughout the study, recommending literature to help expand our racialized understandings, and reviewing and providing insight into the findings and conclusions. Second, transferability of qualitative case studies is arguable, but not assured. Although the findings ring true given our own experiences in such schools (including serving as a school administrator), they clearly will manifest themselves differently in different urban schools nationally. Third, the believability and accuracy of the participant responses may be questionable given the political nature of the principalship and the need for schools (and principals) to have a positive public image. To overcome this challenge, the study adopted a threeinterview schedule, which built rapport and trust between researcher and participant over a period of approximately one month. 


\section{Study Participants}

The 10 principals who participated in the study all contended with similar educational circumstances characteristic of segregated schools in the urban United States: majority-Black students, majority-White teachers, and high percentages of students qualifying for free and reduced price lunch. Although the schools were demographically similar, the principals themselves varied by years of teaching and years as an administrator. Where the participants grew up was associated with their race: all five Black principals grew up in urban areas and attended city public schools (with the exception of Christy who moved to the suburbs in fourth grade) and all five White principals grew up in what they described as small towns or suburbs (see Table 1). Given this context, we were unsurprised at the varying degree of racialized responses: ranging from Dan's casual observation of "I went to school with all White kids" to Victor's painful recollections of the racism of the White students in the integrated school he attended during the era of desegregation.

Table 1

Participant characteristics

\begin{tabular}{|c|c|c|c|c|c|c|}
\hline Ella & $\begin{array}{l}\text { Small } \\
\text { Town }\end{array}$ & $\begin{array}{l}\text { White } \\
\text { Female }\end{array}$ & $92 \%$ & $72 \%$ & $82 \%$ & $\begin{array}{l}5 \text { years teaching } \\
18 \text { years administration }\end{array}$ \\
\hline Victor & Urban & $\begin{array}{l}\text { Black } \\
\text { Male }\end{array}$ & $84 \%$ & $89 \%$ & $78 \%$ & $\begin{array}{l}3 \text { years teaching } \\
12 \text { years administration }\end{array}$ \\
\hline Debbie & $\begin{array}{l}\text { Small } \\
\text { Town }\end{array}$ & $\begin{array}{l}\text { White } \\
\text { Female }\end{array}$ & $93 \%$ & $97 \%$ & $93 \%$ & $\begin{array}{l}9 \text { years teaching } \\
5 \text { years administration }\end{array}$ \\
\hline Caroline & Suburb & $\begin{array}{l}\text { White } \\
\text { Female }\end{array}$ & $85 \%$ & $93 \%$ & $81 \%$ & $\begin{array}{l}10 \text { years teaching } \\
7 \text { years administration }\end{array}$ \\
\hline Christy & $\begin{array}{l}\text { Urban/ } \\
\text { Suburb }\end{array}$ & $\begin{array}{l}\text { Black } \\
\text { Female }\end{array}$ & $94 \%$ & $78 \%$ & $74 \%$ & $\begin{array}{l}14 \text { years teaching } \\
8 \text { years administration }\end{array}$ \\
\hline Earl & $\begin{array}{l}\text { Small } \\
\text { Town }\end{array}$ & $\begin{array}{l}\text { White } \\
\text { Male }\end{array}$ & $88 \%$ & $97 \%$ & $83 \%$ & $\begin{array}{l}18 \text { years teaching } \\
15 \text { years administration }\end{array}$ \\
\hline Daniel & $\begin{array}{l}\text { Small } \\
\text { Town } \\
\end{array}$ & $\begin{array}{l}\text { White } \\
\text { Male }\end{array}$ & $94 \%$ & $87 \%$ & $75 \%$ & $\begin{array}{l}10 \text { years teaching } \\
11 \text { years administration }\end{array}$ \\
\hline
\end{tabular}




\begin{tabular}{|c|c|c|c|c|c|c|}
\hline Chad & Urban & $\begin{array}{l}\text { Black } \\
\text { Male }\end{array}$ & $98 \%$ & $97 \%$ & $63 \%$ & $\begin{array}{l}9 \text { years teaching } \\
11 \text { years administration }\end{array}$ \\
\hline Flora & Urban & $\begin{array}{l}\text { Black } \\
\text { Female }\end{array}$ & $98 \%$ & $100 \%$ & $71 \%$ & $\begin{array}{l}23 \text { years teaching } \\
12 \text { years administration }\end{array}$ \\
\hline Pamela & Urban & $\begin{array}{l}\text { Black } \\
\text { Female }\end{array}$ & $92 \%$ & $100 \%$ & $68 \%$ & $\begin{array}{l}18 \text { years teaching } \\
6 \text { years administration }\end{array}$ \\
\hline \multicolumn{7}{|c|}{$\begin{array}{l}\text { Note. } \\
\text { BNH }=\% \text { of student population that identifies as Black, non-Hispanic } \\
\text { FRL }=\% \text { of students eligible for free and reduced price lunch } \\
\text { WT }=\% \text { White teachers employed at the school }\end{array}$} \\
\hline
\end{tabular}

\section{Findings}

The data analysis generated three themes. First, the study found stark differences in how principals described experiencing and engaging racism and race-based situations in their schools. These differences seemed guided by the principals' own racialized background experiences. Second, principals seemingly engaged their moral agency by describing how they used their positional power to intervene in racist situations they described as wrong. Third, principals articulated their understandings of leading in a context of fear in which it was evident to them that the White teachers were afraid of the perceived verbal and physical aggression of Black parents and of their Black students. These three themes are presented next, illustrated with interview passages.

\section{Shades of Color-Conscious Leadership}

Authors such as Mabokela and Madson (2005), Brooks and Jean-Marie (2007), and Touré (2008) suggest that a principal's race may indicate to what extent they acknowledge and engage race and racism in their schools. While the data from this study in the main supports this notion of a racial divide in principals' racialized perspectives, it also points to complexities. Instead of a definitive-Black-and-definitive-White racialized leadership model, data from this study suggest that principals, both Black and White, exhibited various gradations of color-conscious leadership; that is, with respect to their awareness and engagement of race-based situations in their schools. These gradations were linked to the principals' own racialized background experiences. Such experiences tended to shape how they both experienced and engaged race and racism. The data suggest four relationships between the principals' racialized 
backgrounds and how they both experienced and engaged race and racism in their schools: (a) emotive, (b) desensitized, (c) ambassadorial, and (d) disengaged.

The emotive principal. Three Black principals - Victor, Christy, and Pamela - had similar racialized background experiences. All three attended K-12 schools with predominantly White peers (due to busing or moving to the suburbs) and described various racist acts of peers, teachers, and administrators. Christy, for example, described how the White teachers in a majority-White school denied her learning opportunities:

It's almost like they pushed me through the cracks, because I remember thinking - I remember feeling that when I was at school-you know I'd raise my hand, I wouldn't get to answer. They would never let me answer a question. They would never let me ask a question. When I look back, it was like I was systematically denied engagement and access. And so I remember distinctly after a while just giving up and just looking out the window all day at the squirrels, at the oak trees. I remember that. I remember that, and it was a sad thing.

These three principals tended to tie their racialized experiences to a broader understanding of race and racism in United States, such as the culture of power and privilege; living in two worlds, one White and one Black; and the denigration of Black males in the media and the influence of prevalent imagery on the psyche of White teachers who teach Black children.

Victor, Christy, and Pamela would often become emotional when discussing what they perceived as racist teacher behaviors in their schools, expressing hurt, anger and frustration as they recalled the mistreatment. One such situation described by Christy was the condescending and judgmental ways her teachers addressed Black parents and their "oblivion to appropriateness or being sensitive," such as one male teacher talking about "colored guys" in a condescending way. According to Christy, this conversation "equated to that massa-boy kind of thing. Now, that's not okay!" Similarly, Pamela angrily claimed that her White teachers "don't know how to talk to Black people, period."

When engaging teachers in these situations, this group of principals described galvanizing conversations. Pamela recollected one such conversation with a judgmental teacher, to whom she responded, "I don't care what your opinion of that parent is. I don't care what you think they look like. I don't care what you think they should do with their lives, that's none of your business!" These principals also spoke of their own experiences with racist teacher behaviors. Victor, for example, expressed frustration with the "audacity" of some teachers who, he said, attempted to sabotage his leadership efforts because he was Black. He stated:

I'm not naïve enough to accept the fact that issues of race are not prevalent to this day. But if you're in a setting and the majority of the kids that you're teaching are African American and you are going after someone simply because they are Black, that doesn't make sense! 
The desensitized principal. Only one participant, Debbie, a White principal, fell into this second category. Debbie grew up in a small town where she described observing overt racist behavior from family members such as her uncle making up "little jingles with the $\mathrm{N}$ word in it" - which her brother would then repeat. She also recalled her grandmother's racist behavior:

I remember in high school going to my great grandma's house for dinner and we were all in her house and a family must have looked at the house across the street and from what I remember of the conversation they had to be Black because she said "we had some darkies looking at the house across the street" and it was just how she referred to them and they kept having this conversation about the "darkies."

Debbie explained that she understood these behaviors to be wrong because of her mother's attitude that it "was not okay" to behave in racist ways. When describing her racialized experiences in her all-Black school, Debbie tended to express a sense of cultural curiosity. She described her amazement at the differences between her and her Black students' hair, skin, and dialect, what she referred to as "ghetto slang."

Although Debbie spoke of her background experiences with race and racism in ways that would indicate a high level of racial awareness and she seemed keenly aware of both the physical and (some) cultural differences between the White teaching staff (and herself) and the Black students, she described herself as being "desensitized" to the influence of race for the children in her school. Debbie stated, "It's a cultural desensitivity... because it just becomes a part of everyday life." As a result, instead of engaging race in her school, Debbie described devoting much of her leadership time and energy to engaging poverty. When she described working with her struggling teachers, she tended to attribute their classroom difficulties to a lack of understanding of poverty-induced barriers such as a lack of food or heat in the home and how these circumstances influence children's ability to learn at school. Debbie commented that "it's about money-gaps, not racial-gaps." Privileging class consciousness over race consciousness in this way, according to some authors, may be indicative of the US society's view of poverty as a surmountable circumstance while there is nothing one can do about being Black (Singlton \& Linton, 2005).

The ambassadorial principal. This third category included one White principal, Ella, and two Black principals, Chad and Flora. All three described growing up in racially homogenous neighborhoods and attended K-12 schools that reflected their own race and culture. They depicted their teachers as supportive mentors who pushed them to become academically successful and who nurtured the development of their character.

When speaking of their race-based experiences, this group of principals tended to speak with equanimity and described engaging racialized situations in their school in straightforward and transparent ways. They described 
approaching race-based conversations with teachers in an ambassadorial fashion focused on teachers' edification in order to help them understand situations from Black students' and parents' perspectives. Chad, for example, told of helping a White male teacher who was having difficulty relating to his Black students. He recounted telling the teacher:

You know, in the projects, the only White guys that come around here with a tie are either the man who runs the complex who's over the entire complex, who's saying whether you stay or go, or the police. So, you're in a situation where White guy with a tie, that's what you're being seen as. $\mathrm{Me}$, as a Black guy with a suit, I'm the pastor.

Similarly, Flora described helping her "suburban" teachers not to be "offended" by how Black parents communicated, explaining to them:

When a parent is releasing her frustration, it may appear that she's lashing out at you, but she's really not. She's venting because she does not know how to manipulate or how to work the system because the system failed her when she was coming up. And so the only language she knows may be offensive to you, but that's the only way that parent may be able to express themselves [in terms that might get a response from the system]. And nine times out of ten, once they have vented, and they said it, they'll come back, and say, 'I'm sorry. Excuse my language. I'm just going to kill that boy.' It doesn't mean that the parent is really going to kill that boy; it means that she's going to deal with him. But those are the only words that she knows.

Ella described working with teachers that she "knew" had a problem with Black boys and who she perceived targeted them for discipline. She stated:

[Teachers] that I knew were intimidated by African American boys, who saw them as problems, would be obvious to me. If I went down to the [time out] room and the whole room was full of African American boys. They'd usually send a cluster of students out. And frankly the students were happy to be out because they knew it too. Maybe they wouldn't express it as adults or say that, but they did too, they knew it and they would express that the teacher didn't like them, maybe they didn't know why. I knew the teacher had a problem.

Ella stated that over time she had developed the confidence and the communication skills to address these racist behaviors. She recalled telling one teacher who targeted Black boys, "Look, I need to tell you this, and I know it's going to be hard to hear but here's what it looks like. And I showed her the [discipline] data to back it up. Do you know that you're doing that?"

All three ambassadorial principals seemed to surmise directly the racial tilt of situations in their schools and engaged teachers in direct and frank ways to ameliorate the situations. Instead of couching conversations with teachers in political jargon meant to soften the message for staff, these principals described communicating with teachers straightforwardly and using their own insight into 
the lives of Black students and direct observations of mistreatment to increase White teachers' racial awareness for the benefit of students.

The disengaged principal. The fourth category includes three White principals, Earl, Daniel, and Caroline. They all described growing up in small towns that one described as "White America." Both Earl and Daniel talked about having very little "exposure" to races other than their own and were frank that this upbringing limited their worldviews. Caroline, on the other hand, seemed disinclined to speak of any perceived influence her background might have had on her racialized viewpoints (indeed, on her lack of such viewpoints).

All three principals described experiencing race-based situations in their schools somewhat differently. Caroline talked about being "surprised" when encountering strife between her Black instructional aides and her White teaching staff. She described these encounters as "downright hurtful" and contended that the Black aides "called out those [racial] things . . . as an excuse or as a means to manipulate situations." Daniel experienced race in his school with resignation stating, "It's just the way it is . . I'm White. I'm the man," and although he insisted that the mostly-White make-up of his staff was "unfortunate," he expressed pessimistic beliefs regarding the character of Black applicants. He stated:

I don't get a lot of African American folks apply here, and if they do apply here, they're not going to fit here because they don't have the academic background they need to have. They don't have the right attitude. They don't come to work on time.

Earl considered any racialized situations involving teachers having more to do with teachers "making excuses" for students' nonperformance than with race. In addition, although he suggested that there was a history of the White teachers at his school perceiving themselves as superior to the Black parents, he suggested that "no one ever looked at race as being an issue" in this situation.

Though all three participants talked about and experienced race-based situations in their schools differently, they collectively engaged these situations similarly: through conscious disengagement. While mindful of race and racial tensions in their schools, they considered race a non-issue for the education of Black children. Instead each participant consciously chose to disregard racebased situations in their schools in preference for "putting aside issues of who was White and who was African American" and considered people to be "the same regardless of their color." Earl decisively attributed his leadership success in an urban school district to his ability to "not look at a child's skin color" but to focus instead on helping teachers to be "consistent" and "fair" with all students.

Based on these four groups of principals, we are able to consider a possibly more nuanced version of color-conscious leadership than what is currently posited. Evidence from this study suggests that while all principals were conscious of race, they experienced and engaged this consciousness differently in their schools based on their own racialized backgrounds - backgrounds that are only somewhat predictable based on race. Linking a color-conscious model 
directly to skin color (Mabokela \& Madson, 2005; Touré, 2008) may be overly simplistic and may fail to acknowledge the multitude of ways in which principals' own racialized experiences inevitably shape their leadership in schools.

\section{Principals' Moral Use of Power}

The second theme is that principals viewed themselves as moral agents, exercising power to promote the welfare of their students (Doscher \& Normore, 2008). Those principals who recognized and engaged race-based situations in their schools (emotive and ambassadorial leaders) described confronting teachers who behaved in ways they considered wrong. Ella, for example, noted that teachers considered the students and their families as "somebody they couldn't relate to. Dirty. Just not on their same level. Other people." She talked about observing manifestations of these perceptions in the classroom when it appeared that teachers seemed "intimidated" by the Black boys and would consequently "target" them for discipline. Victor reported that teachers gave Black boys disproportionate disciplinary referrals. In his view the source of the problem was the "derogatory" and "belittling" ways teachers treated Black boys. Pamela specifically recalled one teacher who would refer to Black parents as "you people" and then, when parents got angry, expect the principal to defuse the situation.

The most prevalent intervention reported was to confront the offending teacher directly regarding their racist behavior. According to Pamela, "You can't beat around the bush" with such teachers "because you can't give them the opportunity to misinterpret what you said." These "uncomfortable" conversations often resulted in teachers getting "defensive" and trying to "prove that they're not racist." Ella recalled asking teachers questions to help them to "accept responsibility" for their racist behaviors, such as "What were you thinking when you said that?" Documenting such conversations for "due process" was difficult for principals, however, because such a process requires "hard evidence." Such racist behaviors were rarely overt, and principals had to rely on intuition and experience. Pamela stated:

I find it to be so hard to document, your feelings, and your perceptions, and the way you present yourself, those are so very hard to document. When you stand and you make those kinds of comments, whether you come up with a rationale as to why, there is no rationale. It's hard for me to know how to document when I know what you are, it's hard to do.

Although disciplinary action towards such teachers was a challenge, principals described being committed to addressing the behaviors in "direct" ways because, as Ella indicated, "sometimes the stuff that's in a really bad place is the stuff that you have to attack [even if it] is uncomfortable for people to talk about."

A second way principals used moral power was intervening with White teachers who used their own middle-class values as standards to judge their 
largely impoverished Black urban children. Victor suggested that some teachers had difficulty "relating" to the children because what teachers knew and believed was "different from what our kids will experience and be able to see and be able to relate to." Victor maintained that teachers had difficulty considering "how we all have values, but our values may be different, and [perceiving this reality] not to say what [students] value is right or wrong." Chad also suggested that teachers had difficulty understanding "the gray areas" of what right and wrong look like in different communities. He thought that the White teachers are "so far removed from where the kids are coming from that it's hard for them to relate" and that such teachers often had difficulty with students in their classrooms. Principals told of having "personal dialogue" with these teachers to help "put them in a place of understanding" by describing how the lives of students often differ from their own. Still, principals noted, teachers found it difficult to accept "critical feedback" in these situations. Christy responded to these situations by being cognizant of the "culture of power and privilege" in United States and by understanding that this was the teachers' worldview. Her role, she thought, was "seeing their strengths and helping them overcome their weaknesses."

The principals' stories detailed how they experienced such moral obligations and how they engaged their moral use of power to provide a more socially just school environment. Evidence from one principal, Ella, demonstrates that sometimes leaders struggle with their moral use of power and that although these principals seemed confident about when and how they exercised their moral use of power, they sometimes wonder if they are "overly sensitive" or if they have misinterpreted events. Said Ella, "But I think it's critical if you are going to implement any kind of change to be able to take [in] all that stimulus ... and I mean really receive it, and then do something with it." In other words, after-thefact reflection is important for leaders in this context, but even more important, according to Ella, is for leaders to act on these reflective understandings.

\section{Leading in a Culture of Fear}

Some participants spoke of this theme directly, using the word "fear." Others were more circumspect, preferring to use words such as "intimidated" or "uncomfortable." Two fear-based situations that participants described experiencing with teachers included teachers' fear of Black parents and teachers' fear of Black (particularly male) students. Christy, for instance, stated, "I'm just going to be frank with you" when describing her experiences and perceptions of White teachers being fearful of Black parents. Christy stated:

[I] have some [teachers] that are scared. Some of my staff members are scared of my families. Not because my families have given them a reason to be, but because, I'm going to be honest, of how they look. I honestly think that some of my staff is afraid of Black kids. 
In some situations Christy thought that this fear resulted in teachers refusing to talk directly to parents - opting to limit contact by using written notices. Explaining to teachers that "for a lot of Black people, they have an oral tradition. They talk; they are people who communicate verbally" did little good according to Christy. Teachers continued their avoidance maneuver.

Victor observed that when parents came to the school "upset and angry at someone" they tended to speak "loudly" and "boisterously." This communication style, according to Victor, "intimidated" his White teachers into evading parents because they "were admittedly afraid of the parents and how they were interacting." He found this situation problematic because "parents who are trying to advocate for their child" are communicating in a "manner" that the teachers did not "approve of" and so the teachers would "just avoid" them.

Flora also described how the verbal aggressiveness of parents was a challenge at her school where her "suburban" teachers thought parents who called to complain about something were "lashing out at them." She recalled explaining to these teachers that "she's venting ... It's not an attack on you, it's just that they're so frustrated, that's the only way they know how to release it and say it." Flora indicated that "it wasn't easy" for teachers to work through their fear of these situations, but according to her, "They had to."

Participants' comments about teachers' fear of Black parents indicated that teachers were also fearful of physical aggression from parents. When interviewing for her principalship, Christy recalled the teachers on the interview committee asking, "Would you let a parent come and threaten to fight a teacher?" She recalled being taken aback by the question and, after some reflection, concluded that the staff "was afraid" of the possibility that Black parents would physically harm them. Debbie also indicated that her teachers were afraid of parents becoming physically aggressive but in her case she thought, "rightfully so" because, at least in one situation, a parent became so frustrated with a teacher that she threatened "to choke" her. Similarly, Victor described teachers' fear of parents' "volatile" behavior. He recalled having to reassure teachers that parents "have sense enough not to assault you, not in this kind of setting [i.e., at school]."

Participants also spoke of situations where it was evident to them that teachers were "operating out of fear" when working with Black students. Victor considered such fear as related to what he referred to as "murder-death-kill" during "the first ten minutes of a news broadcast." The perpetrators of reported crimes tended to be Black males and Victor speculated that this vilification of Blacks in the media caused teachers to "feel threatened" just being at work. The situation caused him to wonder, "Do we fear for our safety among our kids here?"

Fear of Blacks is a contemporary issue with historical roots in the institute of slavery. The racist perspectives of Whites in the United States were used historically to justify the enslavement of "ignoble savages" who were considered as having "tendencies towards violence" (D'Souza, 1997, p. 60). According to Channing (1970), this mindset led to "a fear of the Negro" as well as a fear of the 
erosion of race control: that is, loss of White control of both the idea of race superiority and of actual Black people. Apparently, the former is more difficult to erode than the later. Indeed, what Hacker (2003) refers to as "the mark of slavery" is salient to this day and continues to instill fear in the White United States. Given this history, the surfacing of White teachers being fearful of Black parents and Black students is predictable, although rarely mentioned with respect to the role of the principals.

\section{Discussion}

The three themes surfaced by our data analysis (shades of colorconscious leadership, principals as moral agents, and leading the context of fear) arguably describe an urban leadership context fraught with complexities. While principals in White rural and more affluent (segregated or diverse) communities are better able to hire and retain teachers whose experiences and values mirror more closely those of the students, urban leaders contend with a teacher workforce largely in open cultural conflict with the student population (see, for example, Jacob, 2005).

Brooks (2012) provides compelling insight into the challenges of leading in predominantly Black schools staffed with majority-White teachers. In his book, Black School White School, Brooks presents data obtained from a series of four interviews with a White teacher, Dustin, who taught English in a majority-Black high school. In his report Brooks (2012) indicated that documenting these interviews was as "difficult to type as they were to hear" (p. 3) as they revealed the teacher's unexamined White privilege, his disrespect and disregard for the culture of his Black students, and his blatantly low classroom expectations. Evidence from this study indicates that urban principals in segregated schools contend with teachers similar to Dustin every day. These principals reported (sometimes angrily) that students in their schools encountered racist White teachers who both fear them and their parents and who blatantly or covertly support the notion that middle-class White values are best overall and should be embraced in Black communities. Considering these circumstances through the lens of critical race theory, segregated, White-staffed schools, such as those in this study, model for Black children the increasingly vicious social hierarchy of contemporary United States and, although some principals described their teachers as caring practitioners, others described many teachers as doing real harm to children. The real harm lies in the not-so-hidden messages of White power and White privilege woven into the social fabric of these schools (Solomon, Portelli, Daniel, \& Campbell, 2005).

This study illustrates that contending with the challenges of race and racism in segregated, White-staffed schools is, according to principal Ella, "lifechanging hard." The work of leading in such schools is made infinitely more challenging by principals' lack of preparation during their principal licensure programs. The study participants indicated that their principal preparation 
programs were of little use to their actual leadership roles in their segregated schools. Many of the principals described being ill-prepared to address (or even identify) the race-based stereotypes and biases that White teachers held (and in some cases, stereotypes and biases held themselves) and the fear ingrained in such teachers. This perspective is consistent with authors writing about principal preparation programs who express considerable concern regarding the lack of meaningful multicultural, diversity, and antiracist coursework (e.g., Young \& Laible, 2000). The lack of exposure to such concepts, according to these authors, results in principals who have a limited understanding of racism and who are ill-equipped to contend with race-based challenges in ways that are conducive to making schooling more equitable.

Given the likelihood that segregated schools will continue to exist and that the teacher candidate pool from which these schools hire will continue to be predominantly White, it is imperative that current and future school leaders develop an understanding of (a) the relevant history and political economy (in the United States: race and racism, especially as it pertains to White cultural and economic privilege); and (b) how the relevant history and political economy manifest in the present, in particular where they work. It would seem logical that licensure programs specifically prepare leaders for the challenges they might face in such schools (in the United States: White-staffed, segregated schools). In this study the challenges included White teachers targeting Black boys for discipline, White teachers' fear of Black parents and students, and the misuse of White, middle-class values to judge Black students and families. Leaders should know how to sponsor the relevant conversations and actions that confront, disable, and replace common unfair practices. The nuances of cultural ignorance and prejudice will vary tremendously across the planet, but challenges of this sort will appear wherever ghettoization and exclusion operate forcefully, as they do in the contemporary United States.

\section{References}

Boser, U. (2014, May). Teacher diversity revisited: A new state-by-state analysis. Retrieved from https://www.americanprogress.org/issues/race/report/ 2014/05/04/88962/teacher-diversity-revisited/

Brooks, J. S. (2012). Black school White School: Racism and educational (mis)leadership. New York, NY: Teachers College Press.

Brooks, J. S., \& Jean-Marie, G. (2007). Black leadership, White leadership: Race and race relations in an urban high school. Journal of Educational Administration, 46(6), 756-768.

Brooks, J. S., \& Witherspoon-Arnold, N. (2013). Anti-racist school leadership: Toward equity in education for America's students. Charlotte, NC: Information Age Publishing.

Brown v. Board of Education of Topeka, 347 U.S. 483 (1954). 
Channing, S. A. (1970). Crisis of fear: Secession in South Carolina. New York, NY: Simon and Schuster.

Clandinin, D. J., \& Connelly, F. M. (2000). Narrative inquiry: Experience and story in qualitative research. San Francisco, CA: Jossey-Bass.

Clandinin, D. J., Pushor, D., \& Orr, A. M. (2007). Navigating sites for narrative inquiry. Journal of Teacher Education, 58(1), 21-35.

Delgado, R., \& Stefancic, J. (2001). Critical race theory: An introduction. New York, NY: New York University Press.

Delpit, L. (1995). Other people's children. New York, NY: New Press.

Dixon, A. D., \& Rousseau, C. K. (2005). And we are still not saved: Critical race theory in education ten years later. Race Ethnicity and Education, 8(1), 727.

Doscher, S. \& Normore, A.H. (2008). The moral agency of the educational leader in times of national crisis and conflict. Journal of School Leadership, 18(1), 8-31.

D'Souza, D. (1997). Ignoble savages. In R. Delgado \& J. Stefancic (Eds.), Critical White studies: Looking behind the mirror. (pp. 55-65). Philadelphia, PA: Temple University Press.

Evans, A. E. (2004). How high schools respond to the dramatic demographic change: A case of order and discipline. (Doctoral dissertation). Retrieved from Proquest Dissertations and Theses. (3139929)

Ferguson, R. \& Mehta, J. (2004). An unfinished journey: The legacy of Brown and the narrowing of the achievement gap. Phi Delta Kappan, 8(9), 195200.

Hacker, A. (2003). Two nations: Black and White, separate, hostile, unequal. New York, NY: Scribner.

Horsford, S. D., Grosland, T., \& Gunn, K. M. (2011). Pedagogy of the personal and professional: Toward a framework for culturally relevant leadership. Journal of School Leadership, 21(4), 582-606.

Houck, E. A. (2010). Teacher quality and school resegregation: A resource allocation case study. Leadership and Policy in Schools, 9(1), 49-77.

Howard, G. R. (2006). We can't teach what we don't know: White teachers, multiracial schools. New York, NY: Teachers College Press.

Ingersoll, R., \& May, H. (2011). Recruitment, retention, and the minority teacher shortage. Philadelphia, PA: Consortium for Policy Research in Education, University of Pennsylvania and Center for Educational Research in the Interest of Underserved Students, University of California, Santa Cruz.

Jacob, B. A. (2005). The challenges of staffing urban schools with effective teachers. The Future of Children, 17(1), 129-153. 
Ladson-Billings, G. (2005). The evolving role of critical race theory in educational scholarship. Race Ethnicity and Education, 8(1), 115-119.

Lareau, A., \& Weininger, E. (2003). Cultural capital in educational research: A critical assessment. Theory and Society, 32, 567-606.

Love, S., \& Varghese, M. (2012). Race, language, and schooling in Italy's immigrant policies, public discourses, and pedagogy. International Journal of Multicultural Education, 14(2), 1-19.

Mabokela, R. O., \& Madsen, J. A. (2005). Color-blind and color-conscious leadership: A case study of desegregated suburban schools in the USA. International Journal of Leadership in Education, 8(3), 187-206.

McGrady, P. B., \& Reynolds, J. R. (2013). Racial mismatch in the classroom: Beyond Black-White differences. Sociology of Education, 86(1), 3-17.

McMahon, B. (2007). Educational administrators' conceptions of whiteness, antiracism and social justice. Journal of Educational Administration, 45(6), 684-696.

Miles, M. B., \& Huberman, A. M. (1994). Qualitative data analysis: An expanded sourcebook ( $2^{\text {nd }}$ ed.). Thousand Oaks, CA: Sage Publications.

Miles, M. B., Huberman, A. M., \& Saldaña, J. (2013). Qualitative data analysis: An expanded sourcebook ( $3^{\text {rd }}$ ed.). Thousand Oaks, CA: Sage Publications.

Monroe, C. R. (2005). Understanding the discipline gap through a cultural lens: Implications for the education of African American students. Intercultural Education, 16(4), 317-330.

Orfield, G. (2009). Reviving the goal of an integrated society: A 21st century challenge. Los Angeles, CA: The Civil Rights Project/Proyecto Derechos Civiles at UCLA.

Orfield, G., Kucsera, J., \& Siegel-Hawley, G. (2012, May). E pluribus... separation: Deepening double segregation for more students. Retrieved from http://civilrightsproject.ucla.edu/research/k-12-education/integrationand-diversity/mlk-national/e-pluribus...separation-deepening-doublesegregation-for-more students/orfield epluribus revised omplete 2012.pdf

Reardon, S. (2011). The widening achievement gap between the rich and the poor: New evidence and possible explanations. In G. Duncan \& R. Murname (Eds). Whither opportunity: Rising inequality, schools and children's life chances (pp. 91-116). New York, NY: Russell Sage Foundation.

Saldaña, J. (2013). The coding manual for qualitative researchers. Thousand Oaks, CA: SAGE. 
Seidman, I. (2006). Interviewing as qualitative research: A guide for researchers in education and the social sciences. New York, NY: Teachers College Press.

Singleton, G. E., \& Linton, C. (2005). Courageous conversations about race: A field guide for achieving equity in schools. New York, NY: Corwin Press.

Solomon. R. P., Portelli, J. P., Daniel, B., \& Campbell, A. (2005). The discourse of denial: How White teacher candidates construct race, racism and 'White privilege,' Race Ethnicity and Education, 8(2), 147-169.

Sue, D., \& Sue, D. (2008). Counseling the culturally diverse. Hoboken, NJ: John Wiley \& Sons.

Theoharis, G. (2007). Social justice educational leaders and resistance: Toward a theory of social justice leadership. Educational Administration Quarterly, 43(2), 221-258.

Touré, J. L. (2008). "There's some good karma up in here": A case study of White school leadership in an urban context. (Doctoral dissertation). Retrieved from Proquest Dissertations and Theses. (3349246)

Wacquant, L. (2007). French working-class banlieus and Black American ghetto: From conflation to comparison. Qui Parle, 16(2), 5-38.

Young, M., \& Laible, J. (2000). White racism, anti-racism, and school leadership preparation. Journal of School Leadership, 10, 374-415.

\section{Author Contact}

Tonya Milligan (corresponding author): milligan298@yahoo.com

Columbus City Schools, 270 E. State Street, Columbus, OH 43215, U.S.A.

Craig Howley: howleycb@gmail.com

WordFarmers Associates, 75619 Lively Ridge Road, Albany, OH 45710, U.S.A. 